\title{
有限要素法に上る送電線のスリート ジャンプ解析
}

\begin{tabular}{|c|c|c|c|c|}
\hline 正 員. & 登 & & 滋 & (東北電力) \\
\hline 員 & 藤 & 和 & 男 & (東北電力) \\
\hline$A$ & 川 & 英 & & （日 \\
\hline$\Delta$ & 神 & 昭 & 紀 & （日) \\
\hline
\end{tabular}

\section{1. まえがき}

架空送電線路は台風，雷撃，着水雪なよ゙の自然条件 にさらされる。現在，私達がなん亡なく眺好ている送 電線路には，音加ら幾度上なく自然災害们打与のめさ れた人間の悪戦苦闘してきた跡が残されている。

狭险な国土に，過密な人口をか加える我が国では， 導入当初より，2回線垂直配列の送電線が標準形之さ れ，初期導入地の温暖な気象条件汇恵まれて，加なり の信頼性でもって運用されてきた。しかし，電力系統

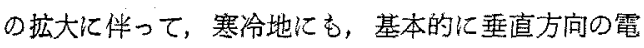
線動摇污弱点をすつ，2回線垂直配列の電線が普及ざ れるに及び，着雪の脱落に起因方る電線跳上がり( リートシャンプ)や，不平等着雪に上る電線流れ込み ががて，雫力の安定供給に重大な影響を与える短絡 事故を発生させることとなった。このため，電線間隔 の应大や，オフセットの増大を四り，対症的対策を行 ない，事故の減少に務めてきた。この対症的対策の集 大性が現在の設計法の骨格をなしている。

近年，より大形の送電線が更汇敏しい地带に設置さ れる気運にあり，合理的な設計を進めるために，電線 動摇を理諭的に解析する必要に迫まら机ている(1)。と ころで，ての種の問題に対する解析法としていくつ加 の方法が既闰開発されている。例えば，跳羅波形を放 物線で近似し，エネルギー法を用いる方法(2)，また， 不均一着雪や部分脱落が忠実に再琴可能な方法として

Sleet Jump Analysis of Transmission Line using Finite Element Method. By Shigeru Tosaka, Member, Kazuo Fujikake, Member (General Research \& Development Center, Tohoku Electric Power Co. inc.), Hidekazu Murakawa, Non-member \& Teruki Myojin, Non-member (Hitachi Research Laboratory, Hitachi Ltd.).

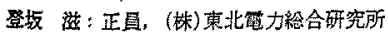

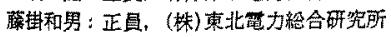

村川英一：韭会易，(株)日立製作所日立研究所

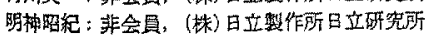

電線の運動を支配主る非線形偏微分方程式を直接離散 化し数値的汇解く方法 ${ }^{(3)}$ 少報告されている。一方, 類 似した問題として，变電機器間りード線の問题が有り てれらに対して，有限要素法，多重振子モデルによる 解析法(4) らが提案されている。

これら比対し，本諭文では，送電楾を構造解析の立 場加ら捕点，有限要素法 (F.E.M.) 在用いた新しい解

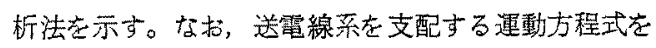
解くという立場加ら見れば，本手法は，上伅举げた解

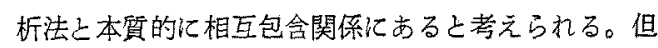
し，詳細に眺狄ば，解法の組織性において，本手法 は，非線形偏微分方程式の直接解法より䇡れている。 また，近敒度において，多重振子モデルより優れてい る。一方, 本手法と同じく有限要素法を用いた手法之 比較する之, 文献(4)飞報告されている有限要素法で は, 大変形の効果加剛性行列の座標变換としてのみ考 慮さ扎ており，乙机は，本文中で述べるUpdated Lagrangian 表示における粗い近似である。竗密には， 更にひずみの非線形成分の影響屯考慮する必要があ り，精度上の疑問か残る。

そこで，著者らは，厳密な大变形理論基檚とした 新しい解法を開発した。以下その概要を示すととを に，既に報告されている解析抽よび実験結果 ${ }^{(3)}$ との比 較を通して，その妛当性を梌証する。

\section{2. 対象とする送電線系}

送電線は图1亿示すように耐張がい儿連または㲘垂 がいし速により鉄塔に架設されるが，耐張がいし連を 越えて隣接する徍間に伝详される運動は，加いし流れ

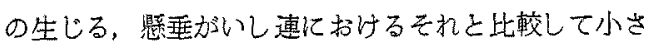
い。徒って，解析対象としては，耐張加いし連に挟ま れた数径間を考元れば良い。また，現実の送電線の状 態老忠実㳻擬するため，解析条件として次にあげる 


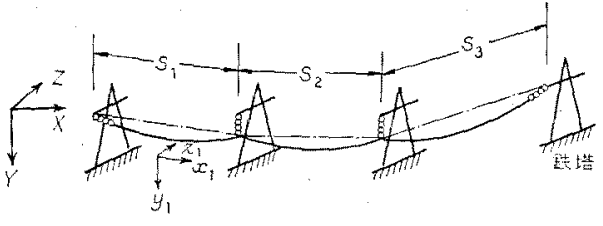

因 1 送電線系

Fig. 1. Transmission line.

項目を満足する必要がある。

（a）最大 10 径間の解析が可能であり，鉄塔は必 ずしむ一直線上偪設置されていない。また，径間長 $S$ は $100 \mathrm{~m}<S<800 \mathrm{~m}$ である。

（b）電線は，重力炢よび，時間的，空間的に変動 する風圧を受ける。

（c）着雪の脱落は，任意の場所で任意の時刻仁起 る。

（d）電線，がいし，扛よび，鉄塔佉，三次元的運動を 行なう。特传電線とがいしは非常に大きく運動する。

(e) 電線は弹塑性体である。

（f）電線はもちるん，がいしの慣性を考虑し，通 常整視される電線の径間方向の慣性も考慮する。

(g) 鉄塔の変形を考慮する。

\section{3. 大変形問題に対する一般理論}

先にあ述べたように，スリートジャンプの理論解析 法として，既に，いくつかの方法が提案されているが 著者引は，前章で示した解析条件を満足し得る手法と して有限要素法を採用した。一般に，有限要素法は， 系が平衡状熊にあるときに，全ポテンシャルエネルギ 一が停留するととを示す変分原理(5)记をの基礎を固い ている。なお，スリートジャンプは，大変形問題であ る。そこで，ここでは三次元問題における大変形問題 に対する変分原理の一般諭を，静的弹烧問題を例とし て説明する。

大変形問題では，微小变形問題と暴なり，まず：工 ネルギーを始め，応力，ひずみなどを定義するための 基準座標を正しく定めておく必要がある。基準座標の 探り方仙，いわゆる゙Total Lagrangian之Updated Lagrangian 表示の 2 通りが考えられる。いずれの場 合䎲も実際の解析では，荷重（または時間）を段階的 飞增加させる増分法が採用されるが，前者ておいては 変形する前の無負荷状龍にある物体中の物質点が持つ 空間座標が基準座標となる。従って，乙の場合，基準 座標は全ての增分の間，不变である。一方；後者代お いては，增分の一段階前の解が既知であることから， この段階での変形した物体中の物質点が持つ空間座標
を基準座標とするものであり，基準座標は增分ごとに 変化する。本質的に虫，而者は，同値であるので，基 準座標の变換を必要としない Total Lagrangian 表示 を用いる。この之き，一般三次元問题における全ポテ ンシャルエネルギー $\pi$ は, 変位 $u_{i}$ の関数しして, 次 のように表わさ礼る。

$$
\begin{aligned}
& \pi\left(u_{i}\right)=\int_{V_{a}}\left\{W\left(g_{i j}\right)-\rho_{0} g_{i} u_{i}\right\} d V \\
& -\int_{S_{0}} t ; u_{i} d S
\end{aligned}
$$

ことで， $V_{0}$ : 変形前の物体が占める体皘

$S_{0}:$ 变形前の物体の表面積

$W:$ ひずエネルギ一密度

$g_{i j}:$ Green Lagrange のひずみ成分

$\rho_{0}:$ 变形前の物体の密度

$g_{i}:$ 単位質量当りの物体力

$t_{i}$ : 物体表面儿㗢くトラタション

(1) 式で与えら机た全ポテンシャルエネルギーの停 留条件は，之の第一変分がゼロになるというととであ りとれより，次式淂得らる。

$$
\begin{aligned}
\delta \pi\left(u_{i}\right)= & \int_{V_{0}}\left\{\frac{\partial W}{\partial g_{i j}} \delta g_{i j}-\rho_{0} g_{i} \delta u_{i}\right\} d V \\
& -\int_{S_{0}} t_{i} \delta u_{i} d S=0 \ldots \ldots \ldots \ldots .
\end{aligned}
$$

更伅，粠成方程式，むなわち，

$$
\frac{\partial W}{\partial g_{i j}}=\sigma_{i j}: 2 \text { nd Piola-Kirchhoff Stress }
$$

なる関係を用いて (2) 式を書き換党る上次式を得る。

$$
\delta \pi\left(u_{i}\right)=\delta U-\delta W=0
$$

ここで,

$$
\begin{gathered}
\delta U=\int_{V_{0}} \sigma_{i j} \delta g_{i j} d V \\
\delta W=\int_{V_{0}} \rho_{0} g_{i} \delta u_{i} d V+\int_{S_{0}} t_{i} \delta u_{i} d S
\end{gathered}
$$

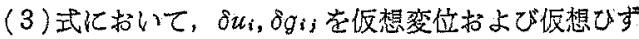
み上解歌すると，仮想内部仕事 $\delta U$ と仮想外部仕事 $\delta W$ 加等しいことを示吉仮想仕事の原理となる。すな わち,

$$
\delta U=\delta W
$$

以上，静的弾性問題について一般論を述へたが，動 的問題の場合にも，慣性力を物体力と考えることによ り，(4)式が適用できる。これ以降の定式化汇执いて

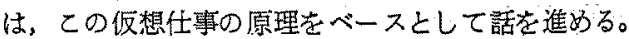

\section{4. スリートジャンプ解析の問題点}

前章では，大变形問題を解析するための基礎之なる 
理論は，既に確立されていることを示したが，スリー トジャンプ解析は，非常に特殊で市り，解決していか なりればならない問題がいくつか有る。すなわち，

（a）Total Lagragian 表示では，無負荷の状態を 基準座標として選ふ心必要があるが，ての上うな，基準

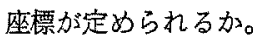

（b）動的解析を始兴前に，静的に平衡した初期 状態を定わる必要がある。しかし，着雪が不均一であ ったり，風在が作用する場合仙，カテナリ一の式や 放物線近似(6)を用いて，初期条件を作ることができな い。スリートジャンプ解析の成否は，上記の問題をい 加に解決するかに加っており，その解決法を次に示 す。

（a）基準座標汇対応する電線の基準状態は，無負 荷状態でなりればならないので，重力，風在，格よび がいしによる拘束を取り図2（a）に示した状態 である。この状態を自然状態之呼ふてとにし，自然状 態仙する電線の長さを自然長 $L^{*}$ とする。本来の基準 座標は，自然状龍沈いて電線に沿った座標 $x_{i}^{0}$ 之考 えられる。しかし，がいし亡電線の間にギャップが生 しるため $x_{i}{ }^{0}$ 浡直接基準座標として用いるのは不都合 である。そてで，园2(b)に示すように自然長 $L^{*} の$ 電線老径間長 $S$ まで伸证した状態を考え，電線汇沿

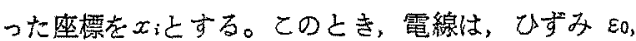
すなわち，

$$
\varepsilon_{0}=\left(S-L^{*}\right) / L^{*}
$$

だけ伸びた状態にある。ところで，自然長さ $L^{*}$ は実 長 $L$ から，電線の弾性的伸び $\Delta L$ を差し引いだの であり，放物線近似を用いた場合，

$$
L^{*}=L-\Delta L=S\left\{1+\frac{(\omega g S)^{2}}{24 T^{2}}-\frac{T}{E A}\right\}
$$

で与えられる。ここで,

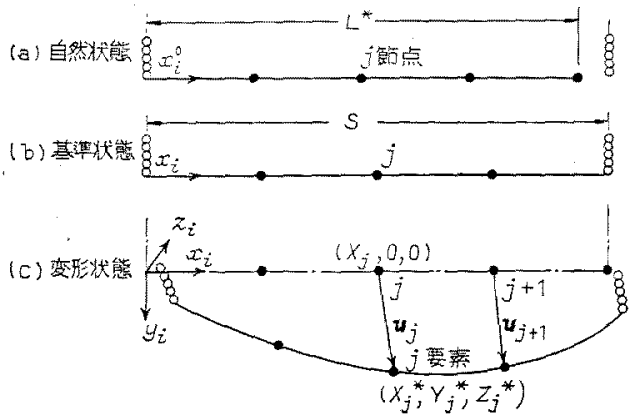

図 2 電線の基準座標之変位

Fig: 2. Reference coordinates and displacement of transmission line.

\section{$T:$ 電線の水平張力, \\ $g:$ 重力加速度， \\ $E:$ 電線のヤング率 \\ $A:$ 電線の断面積}

なお，径間長 $S$ が $100 \mathrm{~m}$ から $500 \mathrm{~m}$ までの電線を 対象としたとき，(6)式で与えられる自然長 $L^{*}$ と径 間長 $S$ との相対差は，1\% 以下の小さい值となる。 従って，(6)式考（5）式に代入し，高次項を繁視する と，ひ岛み $\varepsilon_{0}$ が次式により計算され，その值む $1 \%$ 以下のオーダーに納まる。すなわ方，

$$
\varepsilon_{0}=\frac{T}{E A}-\frac{(w g S)^{2}}{24 T^{2}}
$$

一方，このひずみを用いると，上述で定嘎した二つ の座標系 $x_{i}{ }^{0}$ および $x_{i}$ は，次式代上り関䋆づけら れる。

$$
d x_{i}=\left(1+\varepsilon_{0}\right) d x_{i}{ }^{0}
$$

ここで，E0は 1\% 以下の微小量であるので，1\%の譟

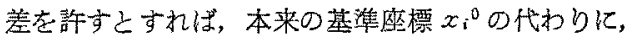

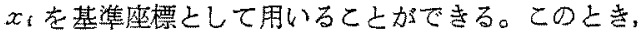
ひずみ $\varepsilon_{0}$ は，初期ひずみとして取り扱う。

（6）初期状態の決定に関しては，有限要素法それ 自身在用いた反復收束計算に上り, 静的平衡状態老求 めるこよができる。

\section{5. 有限要素法による解析手法}

第2 章では，スリートジャンプ解析に执いて考慮す る必要がある要件を示した。この章で，とれら要件 を満たすFEMの定式化を順に追って説明する。

〈5.1〉座標系一般に, 各鉄塔は一直線上に配 置されることは無く，地理的条件により，高低差执よ び水平面内での折徆曲がりを有する。そのため，全体 座標系招よび局所座標系の 2 種の座標柔范導入する。 因1亿示されるごとく，全体座標系 $(X, Y, Z)$ は，文 字どおり系全体を同一の座標系で記述するためのもの であり，Y軸は鉛直下方にとられる。また，局所座標 系 $\left(x_{i}, y_{i}, z_{i}\right)$ は，各径間ごとに定羲され，前章で述へ た電線の基準座標系に対応し，がいし下端を結ぶ見通 し線老 $x_{i}$ 軸とする。これら二つの座標系間の座標変 热は，〔 ( $\left.L_{i}\right]$ を変換マトリックスとして，次式で与元 られる。

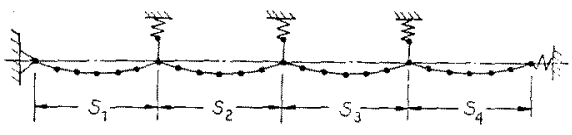

図 34 径間にわたる電線采の F.E.M.モデル

Fig. 3. F.E.M. model for transmission line with 4 spans. 


$$
\left\{d x_{i}, d y_{j}, d z_{i}\right\}^{T}=\left\{L_{i}\right]\{d X, d Y, d Z\}^{T}
$$

な扰，がいし連敊よび鉄塔は，便宜上，全体座標系で 直接記述する。

〈5.2〉 FEM によるモデル化の概要ＦEM で は，解析対象家小さな要素に分割するが，送電線系中 のがいし連は，ほとんど剛体に近いので，1個の楾形 要素(棒要素)として取り报う。また，電稳仕，1径間 を $M_{i}$ 個の線形要素江分割する。图3は，要素分割の 一例を示したむのであり，鉄塔の剈性は等洒なばね上 して評価する。

\section{〈5・3〉 電線に対する要素}

（1）変 位 第 $i$ 径間の電線の局所挙動莸記述 するため，局所座標采 $\left(x_{i}, y_{i}, z_{i}\right)$ を用いる。乙の座標 柔に扔いて，電線上の節点 $j$ 加基準状態沉るときの 位置を $\left(x_{j}, 0,0\right)$ ，また，運動中の位置を $\left(x_{j}^{*}, y_{j}^{*}, z_{j}^{*}\right)$ 亡すると，変位成分 $\left(u_{j}, v_{j}, w_{j}\right)$ は,

$$
\left(u_{j}, v_{j}, w_{j}\right)=\left(x_{j}^{*}-x_{j}, y_{j}^{*}, z_{j}^{*}\right)
$$

に上り定義され，乙机园示したものが図2(c)であ る。また，要素 $j$ 内の変位 $(u, v, w)$ は，䬦点 $j$ および $j+1$ における恣位を用いて線形に内㨉されると仮定 する。このとき, 要素内変位は, 内淿関数を $[F]$ と して，一般に次式で表わされる。

$$
\begin{aligned}
& \{u, v, w\}^{T} \\
& \quad=[F]\left\{u_{j}, v_{j}, w_{j}, u_{j+1}, v_{j+1}, w_{j+1}\right\}^{T}
\end{aligned}
$$

（2）变位ーひずみ関係 電線内の㤂力状態は， 軸方向の芯力のみが存在する一軸応力状態を考えるこ とができるので，ひずみ成分として，軸方向のひずみ ものみを考え机ば息い。このとき，Green-Lagrange のひずみ成分には，次式で与光られる。

$$
\varepsilon=\varepsilon_{0}+\frac{\partial u}{\partial x_{i}}+\frac{1}{2}\left\{\left(\frac{\partial u}{\partial x_{i}}\right)^{2}+\left(\frac{\partial v}{\partial x_{i}}\right)^{2}+\left(\frac{\partial \cdot w}{\partial x_{i}}\right)^{2}\right\}
$$

な书， $\varepsilon_{0}$ は基準座標上ともに導入した初期ひずみであ る。

（3）応力ーひずみ関係 電線の材料として，銅， アルミ，鋼が主に用いられ，それぞれの材料特性は， 非常に異なり，またてれらを複合したより線に至って は，その特性が十分に把握できない。そてで，電線を 単純な弾塑性体と仮定し，その応力ーひずみ関係を図 4 亿示されるように折れ線で近似する。图4亿抢いて， $E_{\iota}, E_{\text {p }}$ は，それぞれ，電線のヤング率㧍よび塑性硬化 率であり， $\sigma_{y}$ は降伏応力である。

（4）電線作用する外力 外力として，着雪お よで電線䎲作用する重力と，空気との相対運動による

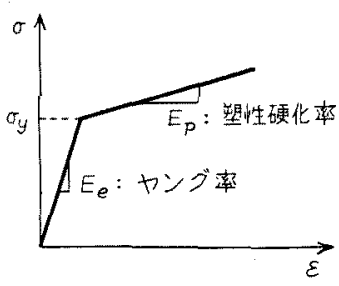

図 4 電線の応力ーひずみ関係

Fig. 4. Assumed stress-strain relation of transmission line.

空気抵抗(風王)を考虑する。このとき，電線の単位長 さ当り作用する外力ベクトル $\boldsymbol{F}_{\boldsymbol{c}}$ は，重力 $\boldsymbol{F}_{\theta}$ お゙よ び空気抵抗 $\boldsymbol{F}_{\alpha}$ の和で与えられる。すなわち，

$$
\boldsymbol{F}_{e}=\boldsymbol{F}_{0}+\boldsymbol{F}_{d}
$$

まず, 重力について考えると，単位長さ当りの重力心 雪む含內た電線の単位長さ当りの質量を $M_{T}$ としたと き，次式が与えられる。

$$
\boldsymbol{F}_{g}=M_{T}\left(g_{x} \boldsymbol{e}_{x}+g_{y} \boldsymbol{e}_{y}\right)
$$

ここで， $\left(g_{x}, g_{v}\right)$ は，局所座標䒺 $\left(x_{i}, y_{i}, z_{i}\right)$ に打ける 重力加速度成分である。

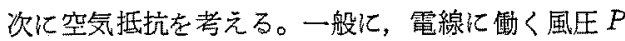
は,

$$
P=(1 / 2) C \rho V^{2}
$$

で与えられる。ここで， $V$ は風速， $\rho$ は空気の密度， またCは，電線の断面形状㧊よび周辺の空気の流れ によって定まる係数である。従って，電線の単位長さ 当りの投影断面皘を $A_{p}$ としたとき，単位長さ当りの 空気抵抗 $\boldsymbol{F}_{d}=\left(F_{x}^{d}, F_{y}{ }^{d}, F_{z}{ }^{d}\right)$ は次式により計算され る。但し，径間方向成分 $F_{x}{ }^{d}$ は無視する。

$$
\left.\begin{array}{rl}
F_{y^{d}}= & -(1 / 2) C \rho A_{p}\left\{\left(\dot{v}-V_{y}\right)^{2}\right. \\
& \left.+\left(\dot{w}-V_{z}\right)^{2}\right\}^{1 / 2}\left(\dot{v}-V_{y}\right) \\
F_{z}{ }^{d}= & -(1 / 2) C \rho A_{p}\left\{\left(\dot{v}-V_{y}\right)^{2}\right. \\
& \left.+\left(\dot{w}-V_{z}\right)^{2}\right\}^{1 / 2}\left(\dot{w}-V_{z}\right)
\end{array}\right\}
$$

ここで, $(\dot{u}, \dot{v}, \dot{u})$ は, 電線の運動速度であり $\left(V_{x}, V_{\nu}\right.$ $\left.V_{z}\right)$ は，局所座標系における風速成分である。

（5）慣性力 先にむ述べたように，電線汇生じ る加速度は，㥜性力の形で等価外力として取り报う。 乙の上き，単位長さ当りの慣性力 $\boldsymbol{F}_{i}$ 仙次式で与えら

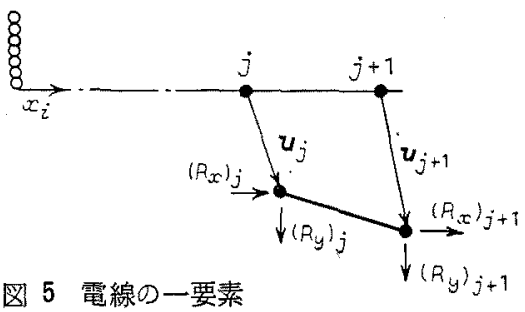

Fig. 5. An element for transmission line. 
れる。

$$
\boldsymbol{F}_{i}=-M_{T}\left(\ddot{u} \boldsymbol{e}_{x}+\ddot{v} \boldsymbol{e}_{y}+\ddot{w} \boldsymbol{e}_{z}\right)
$$

（6）仮想仕事の原理とこでは，図5に示した ような一つの要素を支配する仮想仕事の原理を導く。

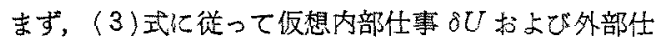

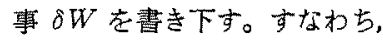

$$
\begin{aligned}
& \delta U=\int_{x_{j}}^{x_{j+1}} A \sigma \delta \varepsilon d x \ldots \ldots \ldots \ldots \ldots . . . .(18) \\
& \delta W=\int_{x_{j}}^{x_{j+1}}\left\{\left[F x_{x^{e}}-M_{T} \ddot{u}\right] \delta u+\left[F y^{e}\right.\right. \\
&\left.\left.-M_{T} \ddot{v}\right] \delta v+\left[F_{z}{ }^{e}-M_{T} \ddot{w}\right] \delta w\right\} d x \\
&+\left[\left(R_{x}\right)_{j+1} \delta u_{j+1}+\left(R_{y}\right)_{j+1} \delta v_{j+1}\right. \\
&\left.+\left(R_{z}\right)_{j+1} \delta w_{j+1}\right]+\left[\left(R_{x}\right)_{j} \delta u_{j}\right. \\
&\left.+\left(R_{y}\right)_{j} \delta v_{j}+\left(R_{z}\right)_{j} \delta w_{j}\right] \quad \ldots \ldots .(19)
\end{aligned}
$$

但し， $\left(R_{x}\right)_{j},\left(R_{x}\right)_{j+1}$ なごは，節点 $j, j+1$ に隣接す

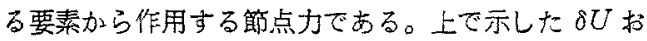
よび $\delta W$ が等しいよ䈯くことにより, 要禁レベルの 仮想仕事の原理が得られる。すなわち,

$$
\delta U=\delta W
$$

（7）増分形の仮想仕事の原理 （20)式は，任意 の時刻に方ける要素の平衡条件を与えるが，落位のる ならず速度および加速度を末知数として含むため，こ れを直接解くことができない。通常この種の動的問题 には，時間を微小区間に打割し，時間経過に従って各 時間間隔の間の変北を增分的に求方增分法加用いら れる。

いま,時刻 $t$ における解が既知であり，てれを〔 $u, v$, $w, \dot{u}, \dot{v}, \dot{w}, \ddot{u}, \ddot{v}, \ddot{w}, \varepsilon, \sigma]<し$ ，特刻 $t+\Delta t$ における 解在 $(u+\Delta u, v+\Delta v, \cdots, \sigma+\Delta \sigma)$ とする。まず，ひず みに注目すると，時刻 $t+\Delta t$ におりるしずるは，ひ

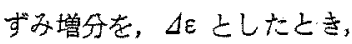

$$
\varepsilon(t+\Delta t)=\varepsilon+\Delta \varepsilon
$$

と表わすととができる。更に，ひずみ增分を変位增分 の線形項 $A^{1} \varepsilon$ 之，2次項 $\Delta^{2} \varepsilon$ に分ける。蓑なわち，

$$
\varepsilon(t+\Delta t)=\varepsilon+\Delta^{1} \varepsilon+\Delta^{2} \varepsilon
$$
$こ こ た$

$$
\begin{aligned}
\Delta^{1} \varepsilon= & \left(1+\frac{\partial u}{\partial x_{i}}\right) \frac{\partial \Delta u}{\partial x_{i}}+\left(\frac{\partial v}{\partial x_{i}}\right)\left(\frac{\partial \Delta v}{\partial x_{i}}\right) \\
& +\left(\frac{\partial w}{\partial x_{i}}\right)\left(\frac{\partial \Delta w}{\partial x_{i}}\right) \quad \ldots \ldots \ldots \ldots \ldots(23) \\
\Delta^{2} \varepsilon= & \frac{1}{2}\left(\frac{\partial \Delta u}{\partial x_{i}}\right)^{2}+\frac{1}{2}\left(\frac{\partial \Delta v}{\partial x_{i}}\right)^{2}+\frac{1}{2}\left(\frac{\partial \Delta w}{\partial x_{i}}\right)^{2}
\end{aligned}
$$

同样に，奻は，

$$
\sigma(t+\Delta t)=\sigma+\Delta \sigma
$$

よ表わすととができ，とれに応力ーひずみ関係と(22) 式を考虚すると次式を得る。

$$
\sigma(t+\Delta t)=\sigma+E \Delta^{1} \varepsilon+E \Delta^{2} \varepsilon
$$

ここで， $E$ は，応力状態によって， $E_{e} ， E_{p}$ のいずれ 汃の茞をとる。

(22)，(26)式で得られた関係古用いると，時刻 $t+\Delta t$ に対する仮想内部仕事 $\delta U$ は，次のように表わされ b。

$$
\delta U=\delta^{3} U+\delta^{2} U+\text { 高次項 }
$$

な书， $\delta^{1} U ， \delta^{2} U$ は，变值增分の線形項および二次項 の変分であり，次式で定義される。

$$
\begin{aligned}
\delta^{1} U & =\int_{x_{j}}^{x_{j+1}}\left\{A \sigma \delta\left(\Delta^{\mathrm{l}} \varepsilon\right)\right\} d x \quad \ldots . . . . . .(28) \\
\delta^{2} U & =\int_{x_{j}}^{x_{j+1}}\left\{A \sigma \delta\left(\Delta^{2} \varepsilon\right)+A E \Delta^{1} \varepsilon \delta\left(\Delta^{1} \varepsilon\right)\right\} d x
\end{aligned}
$$

同様に，仮想外部仕事も線形甹上高次項に分㚈ら机

$$
\delta W=\delta^{1} W+\delta^{2} W
$$

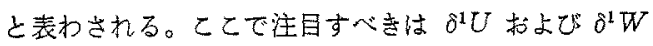
は，時刻 $t$ における仮想仕事てのものであり，時刻 $t$ での解が平衡条件を满足するならば，

$\delta^{1} U=\delta^{1} W$

が成立する。しかし，微小時間区間老線形近似する増 岙法では，一般に時刻 $\boldsymbol{t}$ に招ける解は，平衡条件を完 全に满足せず不平衡力が残るので，乙れを補正する項 として，てれらの項を仮想仕害の原理の中に含めて拉 く。従って增分形の仮想仕事の原理として次式を得る。 $\delta^{1} U+\delta^{2} U=\delta^{1} W+\delta^{2} W$

（8）離散化（32）式で得られた仮想仕事の原理 を(11)式を用いて睢散化すると，節点変位增分 $\{\Delta\lfloor\}$ $=\left\{\Delta u_{j}, \Delta v_{i}, \Delta w_{j}, \Delta u_{j+1}, \Delta v_{j+1}, \Delta w_{j+1}\right\}$ をパラメータ とした離散化式が得られる。すなおち，

$$
\begin{aligned}
& \{\Delta \phi\}^{T}[K]\{\delta \Delta \phi\}+\{\Delta \ddot{\phi}\}^{T}[M]\{\delta \Delta \psi\} \\
& =\{F\}^{T}\{\delta \Delta \phi\}
\end{aligned}
$$

ここで，[K]，[M]，\{F\}は，それぞれ，佣性マトリッ クス，質量マトリックス，荷重ベクトルである。なお (16)式で定義された空気抵抗を速度の非線形関数とし て嗾密に取り扱うとすれば，(33)式において，当然減 复項が現和れる。しかし，空気抵抗の時間変化は，時 間増分 $\Delta T$ に比へて非常に小さいので，空気抵抗は 微小時間增分間で変化しないと仮定した場合，(33)式 が得られる。

〈5.4〉鉄塔－䝮垂がいし連に対する要素＼cjkstart加い し連に対する要素も，先に示した電線に対する要素々 ほぼ同様であるが，次の点において異なる。 
○がい儿運学に，非常に剛な弾性棒と考えた場合に は，その長さが短いので縰掁動们対する固有周期が 非常に小さくなる。そのため，安定な時間積分学行 なううえでの時間增分が小さい值に揤えられ，計算 効率力悪くなる。そこで，加いし連に対いて架空の 粘性を畄入し，その固有間期か，時間增分 $\Delta T$ の 約十倍になるように粘性係数を定める。

○鉄塔の剛性をる含めてがいし連の剛性を考える。 ○空気抵抗肪よじ着雪の重量を無視する。

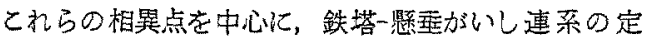
式化を説明方る。

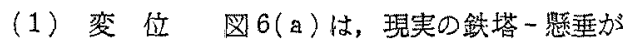
いし連系示したものであり，铁塔の㴊性を（X,Y， Z) 万问のばね定数として評価し，がいし連を一個の 棒要素で近似す狆ば，この系は，図6(b)の上うにモ デル化される。方市，四中の点 $A, B$ は，がいし連の 上下端である。がいし連の基準状態として，鉊直にた れ上った状龍在採用す机代，か心いし連上下端の変位 $\left(u_{a}, v_{a}, w_{a}\right),\left(u_{b}, v_{b}, w_{b}\right)$ は図6(b) に示したように定 義される。

（2）応力ーひずみ関係 既に述べた理由に上り がいし連を粘弾性体として取り扱う。粘弹性体の応力 一ひずる関係仗，一般に次式で表わされる。

$\sigma=E \varepsilon+\eta \dot{\varepsilon}$

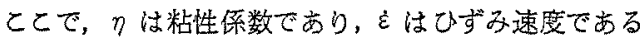

（3）離散化方程式電線の場合に示したと同樣 な過程を経て，仮想任事の原理より次の離散式力得ら れる。

$$
\begin{aligned}
&\{\Delta \phi\}^{T}[K]\{\delta \Delta \phi\}+\{\Delta \phi\}^{T}[C]\{\delta \Delta \phi\} \\
&+\{\Delta \dot{\phi}\}^{T}[M]\{\delta \Delta \phi\} \\
&=\{F\}^{T}\{\delta \Delta \phi\} \ldots \ldots \ldots \ldots \ldots \ldots \ldots \ldots
\end{aligned}
$$

ここで，(C)はがいし連の粘性による減衰マトリック スである。

〈5.5〉鉄塔－耐張がいし連系耐張がいし連の 長さは经間長に比較した場合に非常に短く，電線の㞄 動化対する影響は小さいと考えられる。そとで，耐張
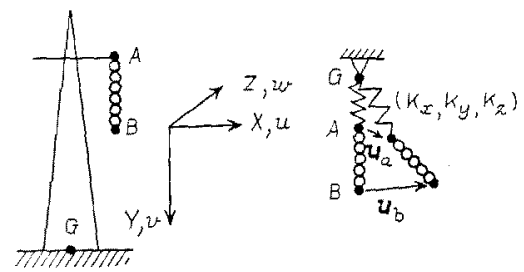

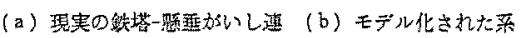

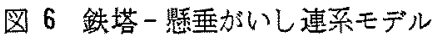

Fig. 6. Idealized tower-insulator system.
か゚いし連を無視し，電線內゙直接鉄塔に接続した形に理 想化多る。

〈5.6〉系全体の仮想仕事の原理送電線哥を構

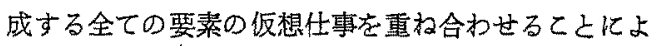

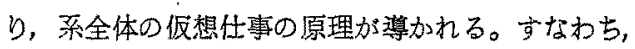

$$
\Sigma \delta U=\Sigma \delta W
$$

但し，乙の重构合わせを行なう際には，局所座標系で 垡わされた電線の仮想仕事を，(9)式を用いて全体座 標系に变換しておく必要がある。との变換により系全 体の仮想仕事の原理は，全体座栖系上で定義された節 点変位を用いて，次のように表わされる。

$$
\begin{array}{r}
\left(\{\Delta \Psi\}^{T}\left[K_{G}\right]+\{\Delta \dot{\Psi}\}^{T}\left[C_{G}\right]\right. \\
\left.+\{\Delta \dot{\Psi}\}^{T}\left[M_{G}\right]\right)\{\delta \Delta \Psi\} \\
=\left\{F_{G}\right\}^{T}\{\delta \Delta \Psi\} \ldots \ldots \ldots . . .
\end{array}
$$

なお，(37)式は，任意の仅想変位 $\{\delta \Delta \Psi\}$ に対して成 立しなければならないので，この条件より，最終的に 次式を得る。

$$
\begin{aligned}
& {\left[K_{G}\right]\{\Delta \Psi\}+\left[C_{G}\right]\{\Delta \dot{\Psi}\}+\left[M_{G}\right]\{\Delta \ddot{\Psi}\}} \\
& \quad=\left\{F_{G}\right\} \ldots \ldots \ldots \ldots \ldots \ldots \ldots \ldots \ldots \ldots \ldots \ldots \ldots \ldots \ldots \ldots \ldots \ldots
\end{aligned}
$$

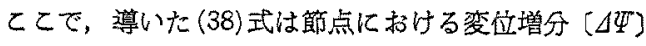
を末知数とする時間に関する常晸分方程式であり， Newmark $の \beta$ 法 $^{(7)}$ 用いて解くことができる。

\section{6. 解析例および考察}

プログラムを検証するため，いくつかのケースにつ いて解析を行ない，その結果を文嗝(3)に報告されて いる，偏微分方程式の直接解法に上る解析結果执よび 実験結果と比較した。ここでは，次のアケースについ て紹介ホる。

Case（1）は，因3に示すように高低差無く直線的 に張られた 4 径間を対象とする。着雪条件としては， 4 经間が全面一栐に翊雪しており，時刻 $t=0$ におい て第 2 径間が一斉脱落するという条件が設定されてい る。なお FEMによる解析で仗，各经間を6 要素分割 し，径間長など詳細な条件として表1の值を用いた。

Case (2) む 4 堡間を対象しし，時刻 $t=0$ において 第 2 径間㧍よび第 4 经間が一斉脱落するという場合で ある。諸条件は，Case（1）とほ同じであるが，一 部翼なる点を表 2 に示す。

Case (3) は時刻 $t=0$ 亿打いて第 2 径間中央 $1 / 30$

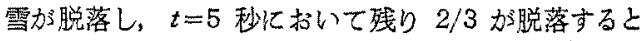
いう例である。なお，とのケースでは第 2 従間を 12 分割した。また Case（1)上異なる条件を表了を示す。

まず, Case (1) の結果を検討する。困7は，第2 径間中央点の跳躍量の時間変化を示したものであり, 
表 1 Case (1) におりる解析条件

Table 1. Detailed condition for Case (1).

\begin{tabular}{|c|c|}
\hline 項 & 容 \\
\hline 電 湶 理 類 & 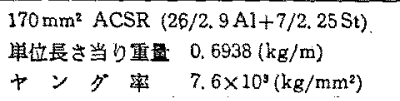 \\
\hline 徒 閖 & $\begin{array}{ll}S_{1}=251.7(\mathrm{~m}) & S_{2}=251.6(\mathrm{~m}) \\
S_{\mathrm{y}}=263.4(\mathrm{~m}) & S_{4}=274.0(\mathrm{~m})\end{array}$ \\
\hline 初期ひする & $\begin{array}{ll}\varepsilon_{0}^{1}=-0.160 \times 10^{-2} & \varepsilon_{0}^{2}=-0.168 \times 10^{-3} \\
\varepsilon_{0}^{3}=-0.164 \times 10^{-2} & \varepsilon_{0}^{4}=-0.228 \times 10^{-2}\end{array}$ \\
\hline 加いし連 & $\begin{array}{ll}\text { が七乚連長さ } & 1.042(\mathrm{~m}) \\
\text { 重 语* } & 52.1(\mathrm{~kg})\end{array}$ \\
\hline 铁塔社初定数 & $\begin{array}{l}K_{x^{2}}=\infty \\
K_{x^{2}}=K_{x^{3}}=K_{x^{4}}=0.714 \times 10^{5}(\mathrm{~kg} / \mathrm{m}) \\
K_{x^{5}}=1,25 \times 10^{5}(\mathrm{~kg} / \mathrm{m})\end{array}$ \\
\hline 薯 & 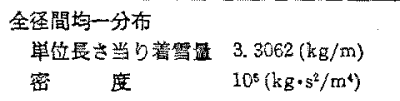 \\
\hline 空気抵抗 & $\begin{array}{l}\text { 空氮密度 } \rho=0.125\left(\mathrm{~kg}_{\mathrm{g}} \cdot \mathrm{s}^{2} / \mathrm{m}^{4}\right) \\
\text { 括茫保数 } C=1.59\end{array}$ \\
\hline 水平張力（計算值） & $\begin{array}{ll}T_{1}=3,211(\mathrm{~kg}) & T_{2}=3,219(\mathrm{~kg}) \\
T_{3}=3,250(\mathrm{~kg}) & T_{\mathrm{t}}=3,266(\mathrm{~kg})\end{array}$ \\
\hline
\end{tabular}

*: 文嗝(1)から植か得られなかったた摊定檤を用いた。

表 2 Case（2）に数汀万解析策件

Table 2. Detailed condition for Case $\{2\}$.

\begin{tabular}{|c|c|c|}
\hline 項 & 内 & 容 \\
\hline 初期ひずみ & $\begin{array}{l}\varepsilon_{0}{ }^{3}=-0.152 \times 10^{-} \\
\varepsilon_{0}{ }^{3}=-0.167 \times 10^{-}\end{array}$ & $\begin{array}{ll}\Rightarrow & \varepsilon_{0}{ }^{2}=-0.154 \times 10^{-2} \\
-2 & \varepsilon_{0}{ }^{4}=-0.186 \times 10^{-2}\end{array}$ \\
\hline 雪 & 全㳗間均一纷布 & $1.706(\mathrm{~kg} / \mathrm{m})$ \\
\hline 水平張力（計算值） & $\begin{array}{l}T_{1}=2,131(\mathrm{~kg}) \\
T_{3}=2,145(\mathrm{~kg})\end{array}$ & $\begin{array}{l}T_{2}=2,132(\mathrm{~kg}) \\
T_{\mathrm{c}}=2,124(\mathrm{~kg})\end{array}$ \\
\hline
\end{tabular}

表 3 Case (3) 飞标ける解析条件

Table 3. Detailed condition for Case (3).

\begin{tabular}{|c|c|c|c|}
\hline I & 目 & 内 & 容 \\
\hline \multicolumn{2}{|c|}{ 初期ひする み } & $\begin{array}{l}\varepsilon_{0}^{1}=-0.173 \times 10^{-2} \\
\varepsilon_{0}^{3}=-0.195 \times 10^{-2}\end{array}$ & $\begin{array}{l}\varepsilon_{0}^{2}=-0.174 \times 10^{-2} \\
\varepsilon_{0}^{4}=-0.219 \times 10^{-2}\end{array}$ \\
\hline 蒡 & 雪 & 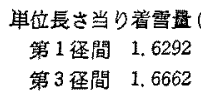 & $\begin{array}{ll}\mathrm{kg} / \mathrm{m}) & \\
\text { 第2 经問 } 1.6992 \\
\text { 第4 经間 } 1.6322\end{array}$ \\
\hline \multicolumn{2}{|c|}{ 水平張力 (棓十算徝) } & $\begin{array}{l}T_{1}=2,067(\mathrm{~kg}) \\
T_{3}=2,081(\mathrm{~kg})\end{array}$ & $\begin{array}{l}=2,082(\mathrm{~kg}) \\
=2,074(\mathrm{~kg})\end{array}$ \\
\hline
\end{tabular}

FEM に上る解(丸印)は，3秒付近まで㣂微分方程式 による解(破線)とよく一致しているが，それ以降汇吉 いては，実験打よび偏微分方程式の解少減敲している

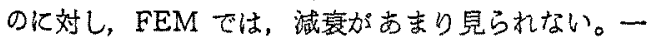
方，第 1 径間および第 2 径間に沾ける電線張力の变化 (図8，图9)に注目すると，FEM の方古実駼近い

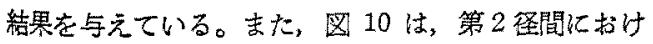
る電線の運動波形をプロットしたものであり，高次波

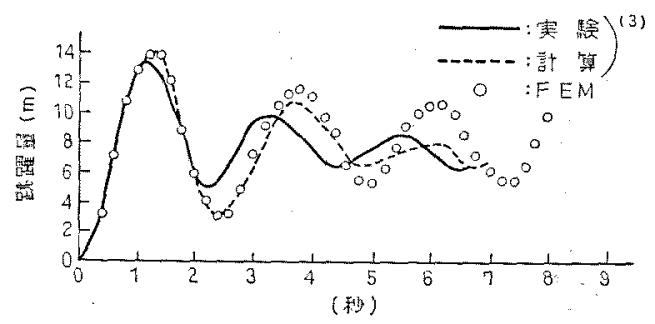

因 7 第 2 径間中央点の跳躍量

Fig. 7. Jumping magnitude of the $2 \mathrm{nd}$ span.

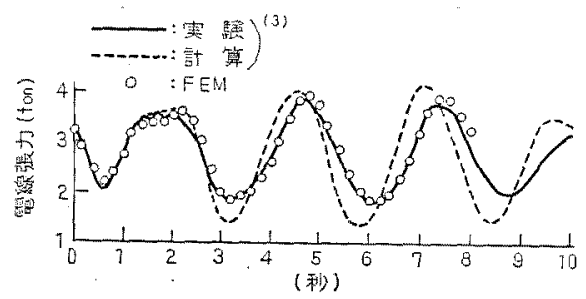

图8 第 1 径間沈ける箧線張力

Fig. 8. Tensile force acting on the lst span.

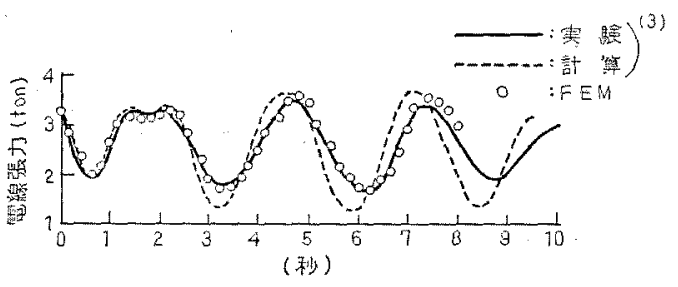

図 9 第 2 㺯間化拈ける電線張力

Fig. 9. Tensile force acting on the 2 nd span.

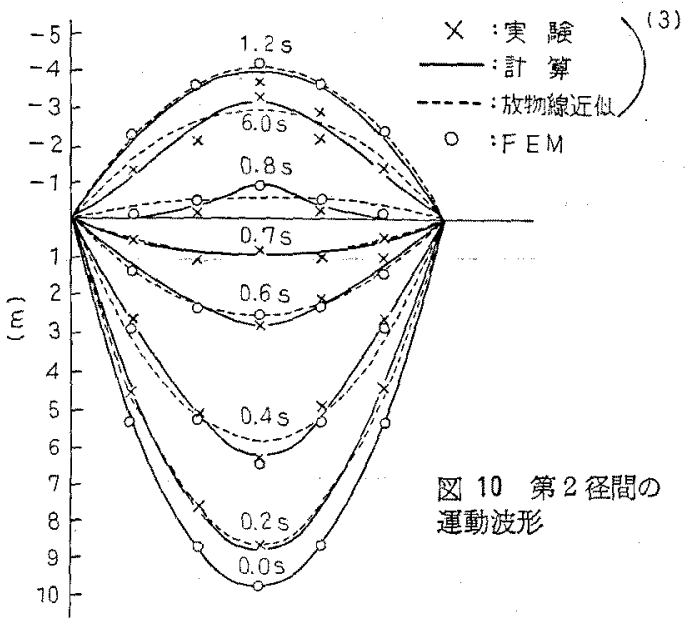

Fig. 10. Deformed configuration of the $2 \mathrm{nd}$ span under motion.

形成分が良く再現されている。ここで，第 2 径間を挟 む第2，第3がい儿に注目すると，図11(a)，(b) 亿 


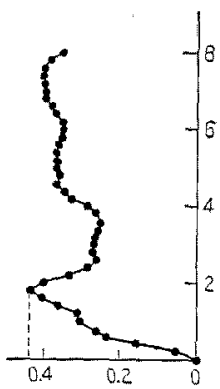
水平恋位 $(\mathrm{m})$

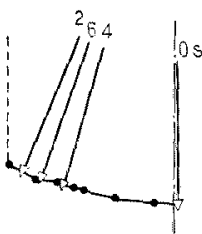

(c)第2がいしの運動軌䟽 (a) 第2がいし下端の

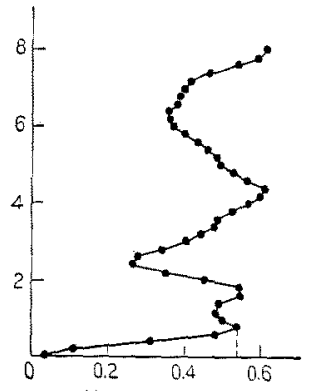

(b) 第3がいし下端の 水平変位 $(m)$

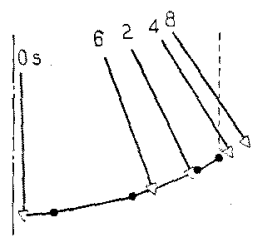

(d) 第3がいしの運動軌跡
目 11 汃しの運動

Fig. 11. Motion of insulators.

示されるように，两がいしはほぼ逆位相で運動し，耐 張がいしから壹い第3がいしの振幅が大きい。图 11 (c)，(d) は，変位の第1 ピークに至るまでのがいし 下端の運動㜞跡と，代表的時刻に拉けるがいし下端近 傍の状態を示しており，第 3 がいしでは，約 $0.6 \mathrm{~m} の$ がいし流れが生じている。なおがいし上端は，鉄塔 の剛性が大きいため，ほ上んど変位しない。

次に，2经間一斉䚀落の場合について検討すると， 第2 经間の跳躍量（図 12) およで電線張力（図 13）の

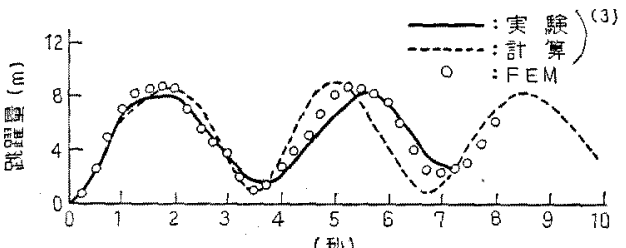

(秘)

图 12 第 2 空間中央点の跳躍量

Fig. 12. Jumping magnitude of the 2 nd span.

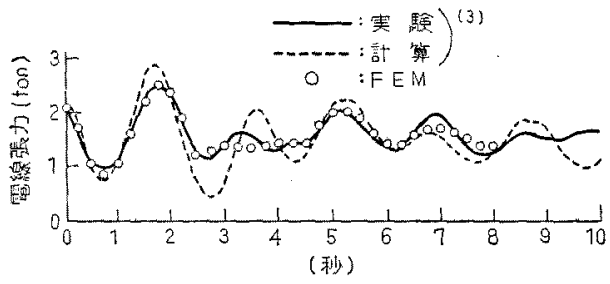

因 13 第 2 经間における電線張力

Fig: 13. Tensile force acting on the 2 nd span:

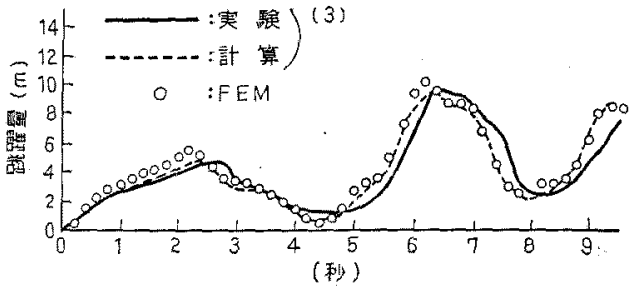

困 14 第 2 经間中央点の跳躍量

Fig. 14. Jumping magnitude of the 2 nd span.

いずれにおいてす，FEM は偏微分方程式による解之 比較して，実験により近い解去无ている。特に，電 線張力が非常に精度良く求められていることが分る。

最後の Case (3) は，第 2 径間が部分脱落する場合 であり，第 2 径間の跳躤䁷を図 14 亿示す。このケー スに関しては，いずれの計算颠も，契験値上よく一致 している。

以上の3ケースについてプログラムを検証したが， FEMによりスリートジャンプがかなり忠害に模擬で きることが明らかとなった。ただ Case(1)において， 第 2 径間での跳躍量に奏験值との差が認められたが， これは害験条件と解折策件が微孥にずれているためで はないかと推測される。

\section{7.むすび}

大変形理論に基づき，FEM を用いてスリートジャ ンプ解析を行なうシミュレーションプログラムを関発

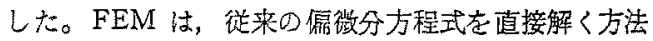
上比較して，その構成が組蟣的かつ単純であり，実用 的に㯪れな解法である。その精度においても，実験と

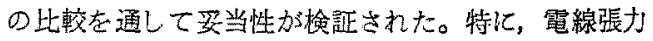
に対して非常に良い結果が得られた。てれは, 本シュ ミレーションプログラムに和いては，電線の径閔方向 の慣性が考慮されているためと推測される。 (昭和 58 年 4 月 15 日受付，同 59 年 4 月 23 日再受付)

\section{文献}

（1）架空送霆線の雪氷害対策：雪水の研究 No，5，日本雪水学 会, p. 195 (昭 48-6)

（2）七里・松湘:「スリートジャンブの理論的孝察」住友電気送

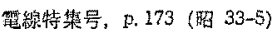

（3）五臊：「北海道塑着雪之対策」北海道電力阵式会社技術研究 所, p. 139 (昭 $52-6$ )

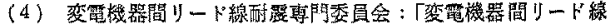

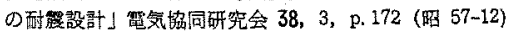

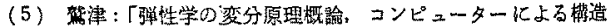

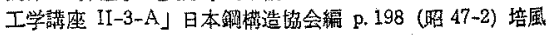
館

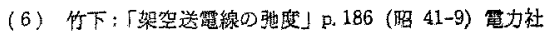

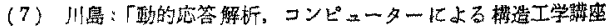

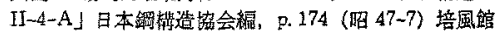

